Tersedia online di: http://ejournal-balitbang.kkp.go.id/index.php/bawal
e-mail:bawal.puslitbangkan@ gmail.com
BAWAL WIDYA RISET PERIKANAN TANGKAP
Volume 11 Nomor 1 April 2019
p-ISSN: 1907-8226
e-ISSN: 2502-6410
BAWAL
Nomor Akreditasi Kementerian RISTEKDIKTI: 21/E/KPT/2018

\title{
IDENTIFIKASI JENIS DAN HUBUNGAN KELIMPAHAN LARVA IKAN DENGAN KUALITAS AIR DI DANAU RANAU, SUMATERA SELATAN
}

\section{IDENTIFICATION OF SPECIES AND RELATIONSHIP OF ABUNDANCE OF FISH LARVA AND WATER QUALITY IN RANAU LAKE, SOUTH SUMATERA}

\author{
Tuah N. M. Wulandari*1, Herlan ${ }^{1}$, Arif Wibowo ${ }^{1}$ dan Sevi Sawestri ${ }^{1}$ \\ ${ }^{1}$ Balai Riset Perikanan Perairan Umum dan Penyuluhan Perikanan, Jl. Gubernur H.A. Bastari No.08, Palembang 30252, Sumatera \\ Selatan-Indonesia \\ Teregistrasi I tanggal: 16 Oktober 2018; Diterima setelah perbaikan tanggal: 03 Oktober 2019; \\ Disetujui terbit tanggal: 08 Oktober 2019
}

\begin{abstract}
ABSTRAK
Identifikasi larva ikan seringkali sulit dilakukan. Belum tersedianya kunci identifikasi untuk spesies larva ikan di perairan umum daratan sehingga belum adanya pedoman untuk dapat mengidentifikasi spesies larva ikan secara morfologi maupun meristik. Penelitian ini bertujuan untuk mengidentifikasi spesies larva ikan melalui sekuen DNA sehingga menghasilkan data spesies yang lebih pasti dan hubungan kelimpahan larva ikan dengan parameter kualitas perairan di Danau Ranau, Sumatera Selatan. Lokasi pengambilan sampel identifikasi jenis dan kualitas perairan di enam stasiun di Perairan Danau Ranau, Sumatera Selatan. Hasil identifikasi dengan menggunakan sekuen DNA ditemukan sepuluh jenis larva ikan. Kesepuluh jenis larva ikan tersebut antara lain Rasbora argyrotaenia, Puntius tetrazona, Oreochromis mossambicus, Oreochromis niloticus, Gambusia affinis, Poecilia reticulata, Mystacoleucus marginatus, Channa striata, Trichopsis vittata, and Trichogaster trichopterus. Sekuen DNA kemudian disejajarkan dengan sekuen referen dari perpustakaan data bank gen untuk mengakar pohon dengan menggunakan program BLAST dari NCBI untuk menemukan identitas yang paling dekat keterkaitannya dengan sampel larva-larva ikan yang dianalisis. Hubungan filogeni spesies diantara takson larvalarva ikan di Danau Ranau berdekatan. Kondisi perairan di Danau Ranau tergolong baik untuk biota perairan seperti larva ikan. Kualitas air merupakan parameter yang menentukan kelimpahan larva ikan di Danau Ranau. Larva-larva ikan antar populasi memiliki jarak genetik yang dekat antar satu dengan yang lain. Kelimpahan larva ikan berkorelasi positif dengan turbiditas dan berkorelasi negatif terhadap parameter daya hantar listrik.
\end{abstract}

Kata Kunci: Larva ikan; Kualitas perairan; Sekuen DNA; Danau Ranau

\section{ABSTRACT}

Identification of fish larva is often difficult. The unavailability of key identification for fish larva species in inland waters so that there are no guidelines for identifying fish larvae morphologically or meristically. This study aims to identify fish larva species from the Ranau Lake waters, South Sumatra through DNA sequences to produce more definitive species data and relationship of abundance of fish larva and water quality of parameters in Ranau Lake waters, South Sumatera. The sampling location of species identification and water quality was six stations in Ranau Lake waters, South Sumatra. The results of the study found the identification of fish larva species using DNA sequence found ten types of fish larva obtained. The ten types of fish larva include Rasbora argyrotaenia, Puntius tetrazona, Oreochromis mossambicus, Oreochromis niloticus, Gambusia affinis, Poecilia reticulata, Mystacoleucus marginatus, Channa striata, Trichopsis vittata, and Trichogaster trichopterus. The $D N A$ sequence was then aligned with the referent sequence from the gene bank data library to root the tree by using the BLAST program from NCBI to find the identity that was closest to the sample of fish larvae analyzed. The relationship of species phylogeny between the fish larva of fish larva in Ranau Lake is close together. Fish larva between populations have close genetic distance from one another. Water quality in Ranau Lake are good for aquatic biota such as fish larva. Water quality is a parameter that determines the abundance of fish larva in Ranau Lake. The abundance of fish larva was positively correlated with turbidity, whereas negatively correlated to conductivity parameters.

Keywords: Fish larva; Fish resource; DNA sequence; Ranau Lake

$\overline{\text { Korespondensi penulis. }}$

e-mail:wulandari.tnm@gmail.com

Telp. 085366733221

DOI: http://dx.doi.org/10.15578/bawal.11.1.2019.33-44 


\section{PENDAHULUAN}

Belum tersedianya informasi mengenai fase awal kehidupan ikan seperti pada spesies larva ikan di perairan umum daratan, baik itu mengenai kunci identifikasi larva ikan sampai spesies secara morfologi dan meristik menjadi kendala utama untuk mengidentifikasi secara konvensional. Identifikasi larvaikan di perairan umum daratan (PUD) dengan sekuen DNA dengan tingkat keakuratan mencapai $100 \%$.

DNA sekuen merupakan teknik yang dapat dipakai untuk mengetahui informasi genetik dan metode untuk memperoleh urutan basa nukleotida pada molekul DNA (Sanger et al., 1977). Pada aspek genetik, identifikasi larva ikan dilakukan dengan metode lebih akurat dengan analisis sekuen DNA. Identifikasi sekuen DNA merupakan teknik identifikasi spesies yang hanya membutuhkan sedikit jaringan tubuh sampel ikan dengan menggunakan gen mitokondria cytochrome oxidase sub unit I (COI) (Wulandari et al., 2018). Fase larva ikan merupakan fase larva, "critical period", dimana tingkat kematiannya sering mencapai $90 \%$. Hal ini disebabkan predator dan lingkungan perairan yang tidak sesuai. Larva ikan biasanya tumbuh dan berkembang pada daerah asuhan (nursery ground) yang terlindungi dimana tersedia pakan alami yang berlimpah (Stouthamer \& Bain, 2012).

Danau Ranau merupakan danau yang terletak di dua propinsi, yaitu propinsi Lampung dan propinsi Sumatera Selatan. Danau Ranau merupakan danau terluas kedua di Pulau Sumatera setelah Danau Toba dengan luas permukaan air lebih kurang 12.590 hektar. Danau Ranau memiliki kedalaman maksimum lebih kurang 229 meter. Danau Ranau terletak pada ketinggian \pm 540 meter di atas permukaan laut dengan volume air lebih kurang $21.950 \mathrm{x}$ $106 \mathrm{~m}^{3}$ (Sulastri et al., 1999). Danau Ranau yang berada di Provinsi Sumatera Selatan memiliki biota ikan yang hidup pada ekosistem danau yang berhubungan dengan aktivitas masyarakat di sekitar Danau yang sangat mengandalkan kekayaan sumberdaya ikan tersebut.

Hebert et al., (2003) menyatakan bahwa gen mitokondria sitokrom c oksidase I (COI) dapat berfungsi sebagai inti dari sistem bioidentifikasi global untuk hewan.
Sistem identifikasi berbasis DNA yang didasarkan pada gen mitokondria, sitokrom c oksidase sub unit 1 (COI) dapat membantu resolusi keragaman. Identifikasi DNA berdasar sitokrom c oksidase sub unit 1 adalah alat dengan akurasi dan resolusi tinggi yang bisa mencapai tingkat perubahan basis tunggal (Marc, 2009). Bahkan, pendekatan ini dapat diterapkan dalam berbagai stadium perkembangan, seperti larva ikan (Marc, 2009).

Syarat awal yang diperlukan untuk menentukan kekerabatan yang dimiliki adalah dengan pengumpulan informasi dan data dasar genetik suatu spesies. (Nugroho et al., 2003). Sampai saat ini belum ada catatan ilmiah mengenai informasi identifikasi larva ikan dengan sekuen DNA di perairan Danau Ranau, Sumatera Selatan. Penelitian analisis sekuen DNA dilakukan untuk melihat hubungan filogeni spesies larva ikan di antara takson yang berdekatan, serta aspek kelimpahan larva ikan sebagai dasar pengelolaan sumberdaya ikan di Danau Ranau.

\section{BAHANDANMETODE Pengambilan Data}

Penelitian identifikasi larva ikan berdasarkan sekuen DNA dan hubungan kelimpahan larva ikan dengan parameter kualitas perairan Danau Ranau dilakukan pada bulan September 2017. Penelitian ini menggunakan metode survei lapangan, bersifat purposif sampling dan dilanjutkan dengan analisis laboratorium. Penentuan stasiun dengan memperhatikan kaedah karakteristik perairan danau yang diduga sebagai habitat larva-larva ikan yang berlindung pada tanaman air. Pengambilan sampel larva ikan dilakukan pada tepian danau ranau yang ditumbuhi tanaman air dienam stasiun, sebagai berikut: (1) Muara Silabung, (2) Dermaga, (3) Way Maissin, (4) Pemandian Air Panas, (5) Desa Lumbok, dan (6) Talang Teluk (Gambar 1). Pada titik-titik sampling juga dilakukan pengambilan contoh untuk pengukuran beberapa parameter fisika kimia perairan pada kedalaman $1-2$ meter (Tabel 1). Parameter fisika kimia perairan yang diamati antara lain suhu air, derajat keasaman $(\mathrm{pH})$, kekeruhan (turbiditas), daya hantar listrik (DHL), kesadahan total, karbondioksida, oksigen terlarut, nitrit, ammonia dan alkalinitas total. 
Tabel 1. Parameter kualitas air yang diamati dalam penelitian di Danau Ranau, Sumatera Selatan pada. September 2017.

Table 1. Water quality parameters observed in research on Ranau Lake, South Sumatera in September 2017.

\begin{tabular}{llll}
\hline No & $\begin{array}{l}\text { Parameter } \\
\text { Parameters }\end{array}$ & $\begin{array}{l}\text { Satuan } \\
(\text { Unit })\end{array}$ & $\begin{array}{l}\text { Metode/Alat } \\
\text { (Methode/Tools) }\end{array}$ \\
\hline 1 & Suhu Air* & ${ }^{\circ} \mathrm{C}$ & Termometer \\
2 & $\mathrm{pH}^{*}$ & $\mathrm{pH}$ meter \\
3 & Karbondioksida* & $\mathrm{ppm}$ & Titrimetri \\
4 & Oksigen terlarut* & $\mathrm{ppm}$ & Titrimetri \\
5 & Kekeruhan* & $\mathrm{NTU}$ & Turbidity meter \\
6 & Kesadahan total* & $\mathrm{mg} / 1$ & Titrimetri \\
7 & Daya hantar listrik* & $\mathrm{ms} / \mathrm{cm}$ & DHL meter \\
8 & Alkalinitas total* & $\mathrm{mg} / 1$ & Titrimetri \\
9 & Nitrit* & $\mathrm{mg} / 1$ & Spectrofotometer Sulfanilamide \\
10 & Ammonia* & $\mathrm{mg} / 1$ & Sprektofotometer Nessler \\
\hline
\end{tabular}

(*) Berdasarkan APHA, 2005.

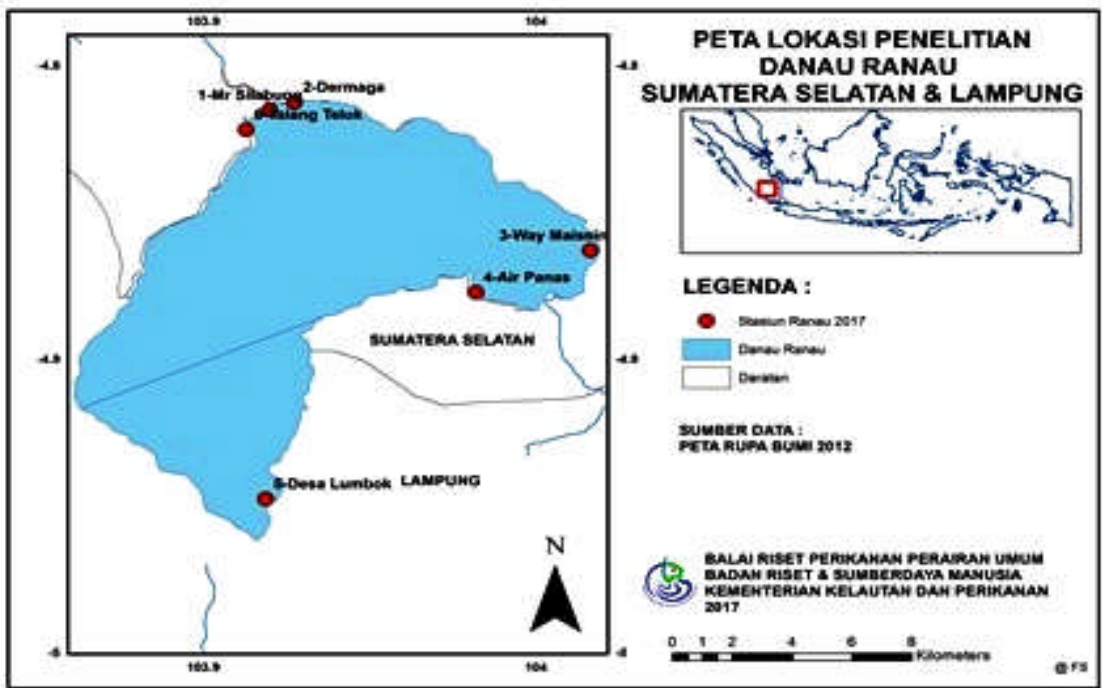

Gambar 1. Lokasi Pengambilan Sampel di Danau Ranau pada September 2017.

Figure 1. Sampling site on Ranau Lake in 2017 September.

Pengamatan larva ikan meliputi jumlah individu dan identifikasi dengan sekuen DNA. Perhitungan kelimpahan dilaksanakan berdasarkan pada jumlah larva yang tersaring pada scoop net (jaring lingkup genggam) selama waktu penarikan dengan asumsi bahwa volume air tersaring sama sebesar 18.462 Liter. Kelimpahan larva ikan dihitung dengan rumus Zava-Garcia \& Flores Coto (1989) dalam Fuentes et al. (2009):

$N=\frac{n}{V t s r}$

dimana:

$\mathrm{N}=$ kelimpahan larva ikan (ind $\left./ \mathrm{m}^{3}\right)$;

$\mathrm{n} \quad=$ jumlah larva ikan yang tercacah (ind);

Vtsr = volume air tersaring $(\mathrm{Vtsr}=1 \mathrm{xt} \mathrm{x} \mathrm{v}) ; \mathrm{l}=$ luas bukaan mulut saringan $\left(\mathrm{m}^{2}\right)$

$\mathrm{t}=$ lama penarikan (menit) dan

$\mathrm{v}=$ adalah kecepatan tarikan (m/menit). Kelimpahan larva ikan dihitung dalam individu/100 $\mathrm{m}^{3}$.
Hubungan keeratan antara kelimpahan larva ikan dengan distribusi karakteristik fisika kimia perairan berdasarkan stasiun penelitian dianalisis dengan pendekatan analisis statistik multivariabel yang didasarkan pada analisis komponen utama (Principal Component Analysis, PCA). Analisis dengan metode PCA menggunakan program Statistika 8. Setijanto et al. (2003) mengatakan PCA merupakan teknik ordinasi yang memproyeksikan dispersi matriks data multidimensi dalam suatu ruang datar dengan cara mereduksi ruang, maka diperoleh sumbu-sumbu baru yang mempresentasikan secara optimal dari sebagian besar keragaman data matriks multidimensi sehingga dapat ditemukan hubungan antar variabel dan antar obyek (individu statistik). Data yang didapat sebelumnya ditransformasikan dalam log $(\mathrm{x}+1)$ (Husnah et al., 2007; Uriarte \& Fernando, 2005). Pada korelasi matriks, data yang digunakan adalah nilai kelimpahan larva ikan terhadap nilai beberapa parameter fisika kimia perairan. Analisa hubungan antar parameter 
dilakukan dengan uji-t pada korelasi matriks dengan signifikansi $\mathrm{P}<0,05$.

\section{Prosedur sampling dan Analisis DNA}

Larva ikan ditangkap dengan menggunakan jaring lingkup genggam (scoop net) yang dimodifikasi dari mesh $1 \mathrm{~mm}$ tanpa sistem penutup. Setiap sampel larva ikan yang didapatkan dimasukkan ke dalam tabung1,5 ml yang telah diisi ethanol absolut (Merck, 99,9\%) serta diberi kode sampel. Sampel-sampel larva ikan kemudian dibawa dan diproses di laboratorium Identifikasi Molekular Ikan di Balai Riset Perikanan Perairan Umum dan Penyuluhan Perikanan Palembang untuk dilakukan identifikasi spesies dengan sekuen DNA.

Sample larva ikan yang telah diberi kode masing-masing diekstrak dengan mengacu pada prosedur Genomic DNA mini kit (Geneaid). Langkah-langkah prosedur kerja Ekstraksi DNA, amplifikasi dan sekuen DNA sebagai berikut:

\section{Ekstraksi mtDNA}

Semua sample DNA diekstrak dari specimen jaringan larva ikan menggunakan genomic DNA mini kit for tissue (Geneaid). Jaringan sampel larva ikan yang disimpan dalam ethanol absolute dicuci dengan air destilata (molecular grade) sebanyak dua kali kemudian disuspensikan dalam bufer STE ( $\mathrm{NaCl} 1 \mathrm{M}$, Tris-HCL 10 $\mathrm{mM}$, EDTA 0,1 mM, pH 8) hingga volume $250 \mu$ l. Jaringan larva ikan ikan dilisis (dipecah/dikeluarkan) dengan SDS (Firstbase, $10 \%$ ) sebanyak $50 \mu \mathrm{l}$ dan proteinase $\mathrm{K}$ (Geneaid) $20 \mu 1$ kemudian dimasukkan dalam oven pada suhu $42^{\circ} \mathrm{C}$ selama 14 jam. Metode ekstraksi DNA selanjutnya mengikuti petunjuk genomic DNA mini kit for tissue (Geneaid).

\section{Amplifikasi}

Amplifikasi menggunakan primer COI (Integrated DNA Technologies) untuk mengamplifikasi sequence DNA. Sebagian fragmen dari gen mitokondria COI diamplifikasi mengggunakan primer universal berdasarkan Ivanova et al. (2007): Fish COI-F (5'ACT TCA AAC TTC CAY AAA GAY ATY GG-3') dan COI-Fish-R (5'-TAG ACT TCT GGG TGG CCR AAR AAY CA-3'). Komposisi reaksi PCR dilakukan dengan volume akhir sebanyak $50 \mu \mathrm{l}$ terdiri atas sampel DNA sebanyak $2 \mu$, nuclease water steril (Firstbase) sebanyak $21 \mu 1$, primer masing-masing sebanyak $1 \mu \mathrm{l}$ dan tambahkan juga PCR premix (My Taq Bioline red mix) sebanyak $25 \mu$ l. Reaksi PCR dilakukan menggunakan mesin thermocycler (BIOER) dengan kondisi sebagai berikut: tahap pradenaturasi $95^{\circ} \mathrm{C}$ selama 1 menit, tahap kedua yang terdiri dari 35 siklus yang masing-masing mencakup tahap denaturasi $95^{\circ} \mathrm{C}$ selama 15 detik, penempelan primer (annealing) pada suhu $55^{\circ} \mathrm{C}$ selama 15 detik, pemanjangan (extention) pada suhu $72^{\circ} \mathrm{C}$ selama 30 detik dan tahap terakhir yaitu pemanjangan akhir (final extention) pada suhu $72{ }^{\circ} \mathrm{C}$ selama 3 menit, dan pengenalan untuk renaturasi $6^{\circ} \mathrm{C}$ selama 5 menit.

\section{Elektroforesis}

Elektroforesis dilakukan terhadap produk PCR untuk diuji dengan menggunakan gel agarose (Firstbase) yang sebelumnya ditambahkan ethidium bromide (Invitrogen) sebanyak $10 \mu \mathrm{l}$ dalam buffer 10x TBE (Firstbase, 1\%). Setelah itu, tuang gel dalam cetakan gel yang telah siap di suntikkan pada masing-masing sumur gel secara berurutan dimulai disuntikkan masing-masing $2 \mu 1$ sampel DNA hasil PCR sesuai urutan nomor sampel, kontrol negatif, kontrol positif dan marker $5 \mu$ l. Proses elektroforesis yang dijalankan pada kondisi $120 \mathrm{v}, 250 \mathrm{~A}$ selama 35 menit. Setelah elektroforesis selesai, gel dimasukkan ke dalam gel dokumentasi (Protein Simple) dan dihidupkan lampu UV gel doc. Analisis keberadaan pita-pita DNA dengan membandingkan kontrol positif, kontrol negatif dan DNA marker (Firstbase).

\section{Perunutan produk PCR dan sekuen DNA}

Produk PCR di atas gel agarose yang berukuran sesuai dengan desain primer yang dimurnikan dengan menggunakan kit purifikasi (Bioline isolate II PCR and gel)dengan mengikuti protokol pabrikan. Produk PCR yang sudah dimurnikan dijadikan cetakan dalam PCR for sequencing dengan menggunakan pasangan primer yang sama dengan ampilfikasi awal. Sampel dikirim ke Macrogen Biotechnologies Co, Ltd, Seoul, Korea Selatan untuk proses sekuensing.

\section{Analisa Data}

Hasil perunutan nukleotida diedit menggunakan perangkat lunak Bioedit secara manual berdasarkan kromatogram (Hall,1999). Runutan nukleotida yang sudah diedit kemudian saling disejajarkan menggunakan Clustal W (Thompson et al., 1997) yang tertanam dalam MEGA 5.0 (molecular evolutionary genetics analysis) (Tamura et al., 2007). Sekuen DNA kemudian disejajarkan dengan sekuen referen dari perpustakaan data bank gen dengan menggunakan program BLAST dari NCBI untuk menemukan identitas yang paling dekat keterkaitannya dengan jenis sampel larva-larva ikan yang dianalisis.

\section{HASIL DAN BAHASAN \\ Hasil}

\section{Kelimpahan Larva Ikan}

Data kelimpahan larva ikan yang diperoleh di setiap stasiun ada pada Tabel 2 . 
Tabel 2. Jumlah jenis hasil identifikasi sekuen DNA dan kelimpahan larva ikan yang didapatkan di DanauRanau,Sumatera Selatan pada September 2017.

Table 2. Number of species identified by DNA sequences and abundance of fish larva obtained on Ranau Lake, South Sumatera in September 2017.

\begin{tabular}{|c|c|c|c|c|c|c|c|c|}
\hline No. & Nama Lokal & Spesies & St.1 & St. 2 & St. 3 & St.4 & St. 5 & St.6 \\
\hline 1. & Sepat Mutiara & Trichogaster trichopterus & & & & & 1 & \\
\hline 2. & Tempalo & Gambusia affinis & & & 5 & 7 & 4 & \\
\hline 3. & Gupi & Poecilia reticulata & 1 & 2 & & & 1 & \\
\hline 4. & Kepiak & Puntius Tetrazona & & & & & & 1 \\
\hline 5. & Kepiat & Mystacoleucus marginatus & & & & & 2 & \\
\hline 6. & Mujair & Oreochromis mossambicus & 9 & 3 & & & 15 & \\
\hline 7. & Nila & Oreochromis niloticus & 1 & 1 & 2 & & 2 & 1 \\
\hline 8. & Seluang & Rasbora argyrotaenia & & & 1 & 1 & & \\
\hline 9. & Sepat Siam & Trichopsis vittata & & & & & 5 & \\
\hline \multirow[t]{3}{*}{10.} & Gabus & Channa striata & & & 3 & & & \\
\hline & Jumlah & & 11 & 6 & 11 & 8 & 30 & 2 \\
\hline & \multicolumn{2}{|c|}{ Kelimpahan larva (individu/100m³) } & 60 & 33 & 60 & 43 & 163 & 11 \\
\hline
\end{tabular}

Kelimpahan larva tertinggi terdapat pada stasiun Lumbok sebesar 163 individu/100m³. Hal ini dikarenakan banyak terdapat tanaman air sebagai tempat berlindung larva-larva ikan. Larva-larva ikan yang ditemukan di Danau Ranau berlindung pada tanaman air yang dominan ditemukan seperti jenis Hydrilla verticillata dan Eichhornia crassipes. Strategi ikan dalam mempertahankan kelangsungan hidup larvanya dengan cara ikan akan menyimpan telur dan larvanya di daerah yang terlindungi (Cole, 2008). Tumbuhan air yang hidup terbatas hanya dibagian tepi Danau Ranau bersifat tenggelam (submersed plants) seperti jenis Hydrila verticillata dan Utricularia sp. (Samuel \& Subagdja, 2011).

Kelimpahan larva terendah ditemukan di stasiun Talang Teluk sebesar 11 individu/ $100 \mathrm{~m}^{3}$. Hal ini dikarenakan pada stasiun ini kondisi perairan terbuka sehingga larva-larva ikan tidak mendapatkan tempat berlindung yang cukup dan berakibat pemangsaan terhadap larva ikan sangat tinggi. Larva sangat rentan terhadap tingkat kematian yang tinggi yang salah satunya disebabkan oleh tekanan pemangsaan dari organisme-organisme pemangsa (Koster \&Mollman, 2000).

\section{Identifikasi Sekuen DNA}

Identifikasi spesies larva ikan dengan menggunakan sekuen DNA dilakukan terhadap 68 larva ikan yang diperoleh dan sepuluh NCBI Genbank. Amplifikasi gen cytochrome oxidase subunit $\mathrm{I}(\mathrm{COI})$ menghasilkan fragmen gen COI berukuran 640-702 bp (Gambar 2). Hasil identifikasi sekuen DNA didapatkan sebanyak sepuluh jenis larva ikan.Sekuen DNA kemudian disejajarkan dengan sekuen referen dari perpustakaan data bank gen untuk dilihat pohon filogeninya dengan menggunakan program BLAST dari NCBI untuk menemukan identitas yang paling dekat keterkaitannya dengan sampel larvalarva ikan yang dianalisis. Ke-sepuluh jenis larva ikan tersebut meliputi Rasbora argyrotaenia, Puntius tetrazona, Oreochromis mossambicus, Oreochromis niloticus, Channa striata, Trichogaster trichopterus, Gambusia affinis, Poecilia reticulata, Mystacoleucus marginatus, dan Trichopsis vittata.

Sebelum penelitian identifikasi sekuen DNA ini belum ada catatan ilmiah mengenai identifikasi larva ikan di Danau Ranau.Pendekatan molekuler melalui aplikasi teknik sekuen DNA dapat menjadi landasan dalam upaya pengelolaan sumber daya ikan di perairan umum. Hasil identifikasi sekuen DNA didapatkan sepuluh jenis larva ikan di Danau Ranau menginformasikan sepuluh spesies ikan air tawar yang diduga memijah di ekosistem Danau Ranau. Hal ini memberikan informasi pentingnya habitat Danau Ranau sebagai tempat pemijahan ikan dan kehidupan ikan.

\section{Analisis Filogeni dan Jarak Genetik}

Posisi organisme pada pohon filogeni didasarkan pada kesamaan genetik mereka satu sama lain. Pohon filogeni seperti tertera pada Gambar 3 menunjukkan hubungan evolusioner yang disimpulkan di antara beberapa spesies larva-larva ikan, genus dan famili. Dendogram NJ (Neighboard Joining) berdasarkan jarak genetik berpasangan menunjukkan segregasi Oreochromis mossambicus dan Oreochromis niloticus dalam satu klaster yang memiliki kekerabatan yang lebih dekat (Gambar 3). Organisme dari spesies yang berbeda dari genus yang sama akan berdekatan satu sama lain di pohon, seperti pada Oreochromis mossambicus dan Oreochromis niloticus. Organisme dari spesies dan genera yang berbeda tentunya didapatkan jarak yang lebih jauh pada pohon filogeni. Rasbora argyrotaenia, Puntius tetrazona, Dermogenys pusilla, Gambusia affinis, Poecilia reticulata, Mystacoleucus marginatus, Channa striata dan Trichopsisvittata pada kelompok lain dengan jarak 
simpul berkisar antara 0,209 menjadi 0,240 (Tabel 3). Estimasi NJ dan estimasi bootstrap dalam penelitian ini menunjukkan jarak genetik minimum $(0,255)$ antara kedua spesies ini (Trichopsis vittata dan Mystacoleucus marginatus) yang menekankan hubungan evolusioner dan juga perbedaannya akhir-akhir ini.

Nilai jarak genetik dilakukan dengan cara mengukur keeratan genetik antara dua individu. Analisis yang paling umum digunakan untuk menduga nilai jarak genetik adalah jarak genetik Nei (1972). Hasil pengukuran jarak genetik didapatkan estimasi secara evolusioner berpencarnya diantara sekuen grup larva-larva ikan. Jumlah substitusi dasar setiap situs dari rata-rata semua sekuen diantara grup ditunjukkan. Analisis dilakukan menggunakan model Kimura 2-parameter menggunakan program MEGA6. Analisis dilakukan pada 78 nucleotida sekuen. Posisi kodon termasuk posisi pertama, kedua dan ketiga. Semua posisi memiliki gap dan dapat dieliminasi data yang hilang.

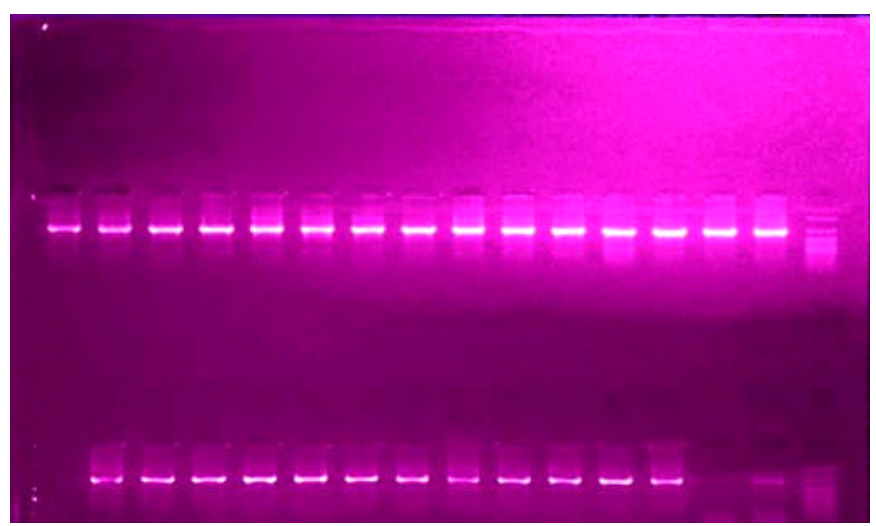

Gambar 2. Profil DNA larva ikan di Danau Ranau hasil amplifikasi fragmen sebagian dari Mitochondria c oksidase subunit-1gen (CO1) pada September 2017.

Figure 2. The DNA profile of fish larvae in Lake Ranau was amplified partial fragment of the Mitochondrial $c$ oxidase subunit-1gene (CO1) in September 2017.

Tabel 3. Jarak genetik rata-rata diantara grup larva-larva ikan.

Table 3. Mean distance between group of fish larva.

\begin{tabular}{lccccccccc}
\hline $\begin{array}{l}\text { Spesies } \\
\text { Species }\end{array}$ & $\mathbf{1}$ & $\mathbf{2}$ & $\mathbf{3}$ & $\mathbf{4}$ & $\mathbf{5}$ & $\mathbf{6}$ & $\mathbf{7}$ & $\mathbf{8}$ & $\mathbf{9}$ \\
\hline $\begin{array}{l}\text { Trichopsis vittata } \\
\text { Oreochromis mossambicus }\end{array}$ & & & & & & & & & \\
Gambusia affinis & 0.209 & & & & & & & & \\
Oreochromis niloticus & 0.254 & 0.221 & & & & & & & \\
Poecilia reticulata & 0.237 & 0.055 & 0.216 & & & & & & \\
Rasbora argyrotaenia & 0.259 & 0.240 & 0.232 & 0.252 & & & & & \\
Mystacoleucus marginatus & 0.229 & 0.233 & 0.238 & 0.226 & 0.261 & & & & \\
Channa striata & 0.255 & 0.231 & 0.271 & 0.217 & 0.268 & 0.191 & & & \\
Trichogaster trichopterus & 0.238 & 0.216 & 0.269 & 0.232 & 0.238 & 0.255 & 0.258 & & \\
Puntius tetrazona & 0.206 & 0.227 & 0.251 & 0.236 & 0.278 & 0.250 & 0.265 & 0.231 & \\
\hline
\end{tabular}




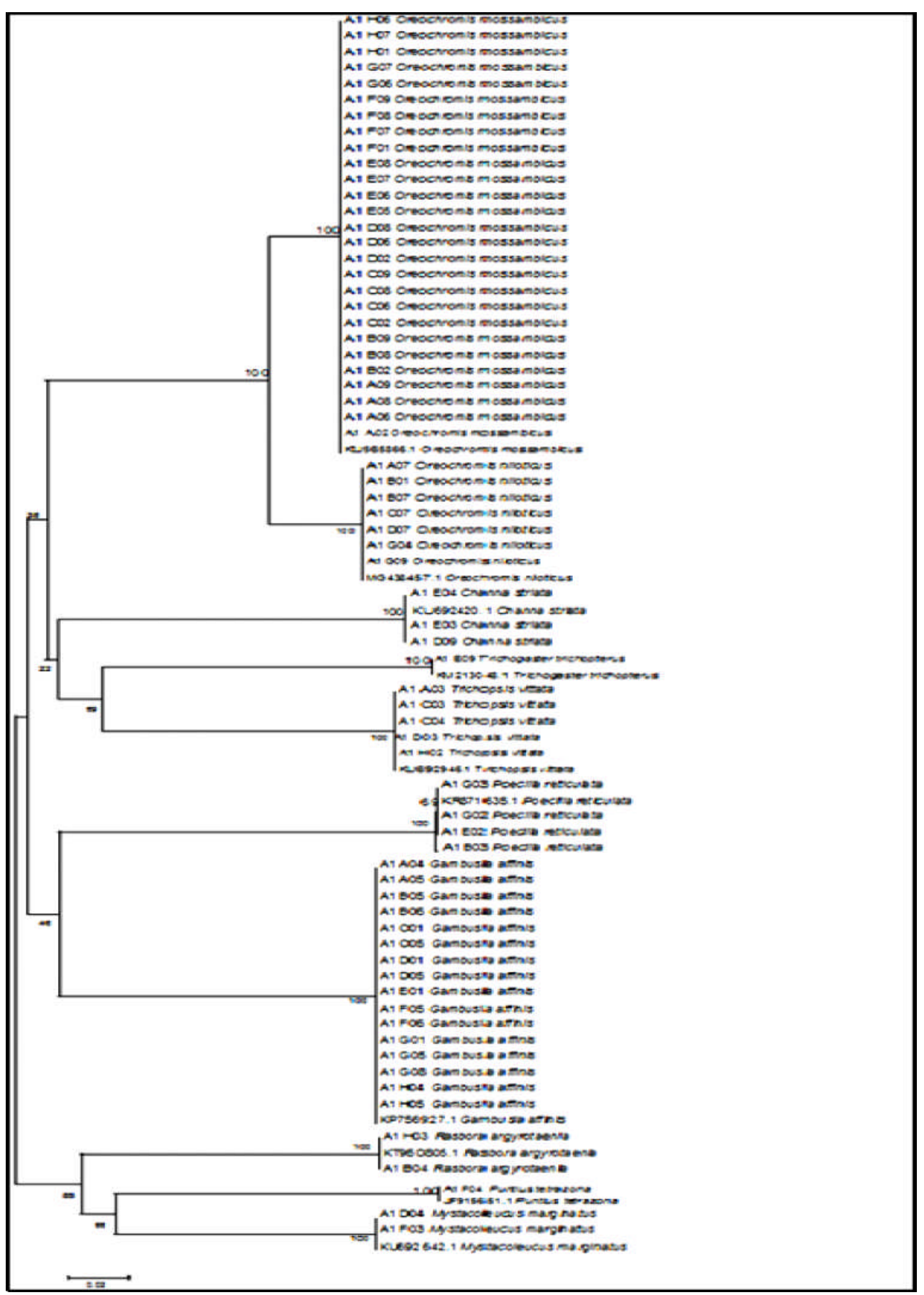

Gambar 3. Analisa pohon neighbor-joining dari COI sekuen larva ikan di Danau Ranau, Sumatera Selatan.

Figure 3. Analysis of neighbor-joining trees from COI sequencing of fish larva in Ranau Lake, South Sumatra.

\section{Karakterisitik Fisika Kimia Perairan Danau Ranau Dihubungkan Dengan Kelimpahan Larva Ikan}

Kecukupan data dari nilai total tiga faktor pembentuk kumulatif yaitu mencapai 91,52\% (>70\%). Gambar 4, menunjukkan hubungan antara parameter fisika kimia perairan dengan kelimpahan larva ikan. Secara jelas tergambar bahwa nilai kelimpahan larva ikan berbanding lurus dengan hampir seluruh parameter dengan signifikansi tertentu, akan tetapi cenderung berbanding terbalik dengan daya hantar listrik (konduktivitas) dan total alkalinitas perairan. Gambar 4, menggambarkan pengelompokan stasiun berdasarkan perbedaan karaktersitik parameter pembentuknya. Pengelompokan stasiun penelitian berdasarkan PCA memperlihatkan adanya empat kelompok stasiun. Stasiun kelompok pertama terdiri dari Muara Silabung dan Way Maissin yang dicirikan oleh kekeruhan (turbiditas) dan oksigen terlarut yang cukup tinggi. Stasiun kelompok kedua terdiri 
dari Pemandian Air Panas dan Talang Teluk dicirikan oleh karbondioksida yang cukup tinggi, dan nilai nitrit yang rendah. Stasiun kelompok ketiga terdiri dari Dermaga dicirikan oleh daya hantar listrik (DHL) dan $\mathrm{pH}$ yang cukup tinggi. Stasiun kelompok keempat terdiri dari Lumbok Lampung yang dicirikan oleh oksigen terlarut dan kelimpahan larva ikan yang tinggi.

Hubungan antar setiap parameter ditunjukkan melalui tabel korelasi matrik pada tingkat signifikansi $\mathrm{P}<0,05$ (Tabel 4). Dari tabel tersebut terlihat secara jelas hubungan antara kelimpahan larva ikan terhadap kekeruhan (turbiditas), total alkalinitas dan daya hantar listrik.
Kelimpahan larva ikan berkorelasi positif dan signifikan dengan turbiditas, sedangkan korelasi dengan parameter daya hantar listrik (konduktivitas) dan total alkalinitas signifikan dan bersifat negatif. Parameter daya hantar listrik memiliki korelasi positif dengan total alkalinitas. Hasil analisa PCA dan analisis korelasi dengan uji-t pada setiap parameter menggambarkan adanya keterkaitan erat antara kelimpahan larva ikan terhadap turbiditas, daya hantar listrik, dan total alkalinitas. Nilai korelasi yang lemah ditunjukkan pada hubungan kelimpahan larva ikan terhadap parameter lain seperti suhu perairan, karbondioksida, ammonia, nitrit dan $\mathrm{pH}$.
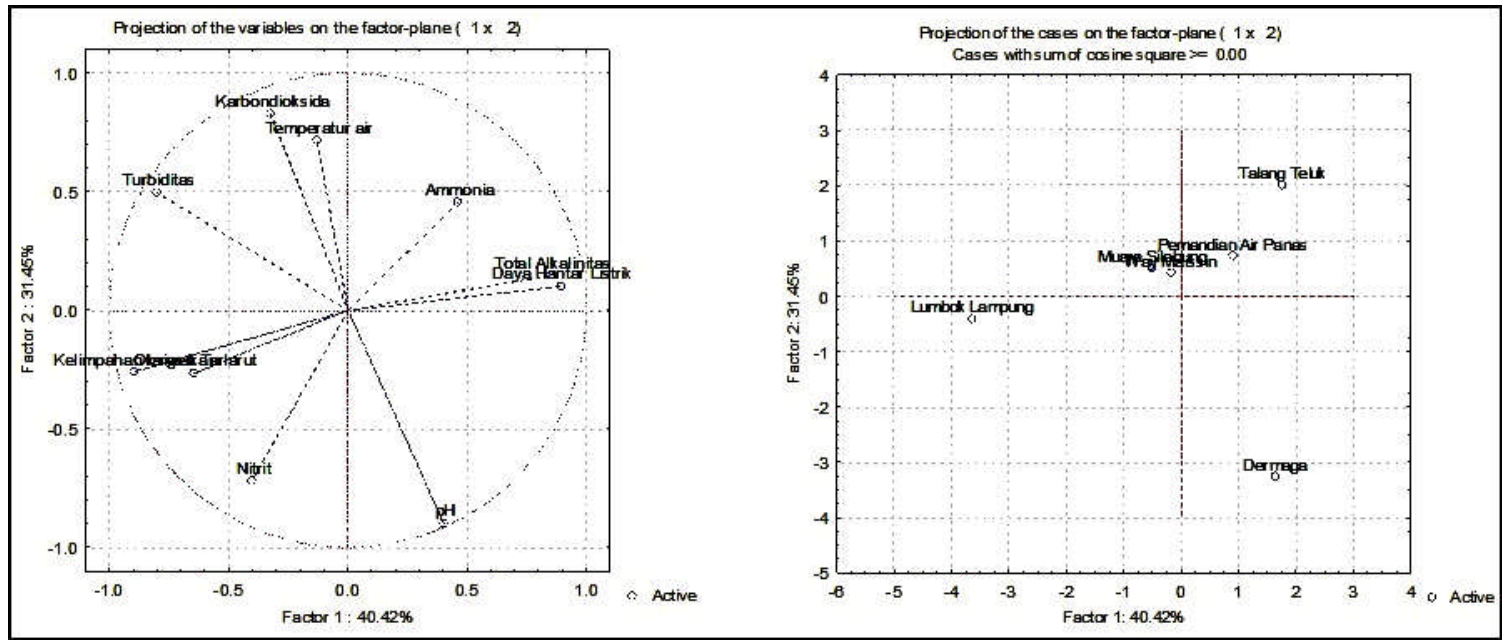

Gambar 4. Grafik analisis dalam Principal Component Analysis (PCA). Sebaran parameter perairan (A) dan sebaran stasiun (B).

Figure 4. Principal Component Analysis (PCA) graph. Waters parameters distribution (A) and station distribution (B).

Tabel 4. Korelasi matriks setiap variabel pengamatan lingkungan

Table 4. Matrix corellation of each enviromental parameters

\begin{tabular}{|c|c|c|c|c|c|c|c|c|c|c|c|c|}
\hline \multirow{2}{*}{ Variabel } & \multirow{2}{*}{ Suhu air } & Daya Hantar & Oksigen & Karbon & \multirow{2}{*}{ A mmonia } & Total & \multirow{2}{*}{ Nitnit } & \multirow{2}{*}{$\mathrm{pH}$} & \multirow{2}{*}{ Turbiditas } & Kelimpahan & \multirow{2}{*}{ Means } & \multirow{2}{*}{ Std Dev. } \\
\hline & & Listnik & Terlarut & dioksida & & Alkalinitas & & & & Larva Ikan & & \\
\hline \multirow{2}{*}{ Variable } & Water & \multirow{2}{*}{ Conductivity } & Dissolved & Carbon & \multirow{2}{*}{ A mmonia } & Total & \multirow{2}{*}{ Nitnite } & \multirow{2}{*}{$\mathrm{pH}$} & \multirow{2}{*}{ Turbidity } & Abundance & \multirow{2}{*}{ Menas } & \multirow{2}{*}{ Std.Dev. } \\
\hline & Temperature & & Oxygen & dioxide & & Alkalinity & & & & of Fish Larvae & & \\
\hline Suhu air & 1,000 & & & & & & & & & & 28,083 & 0,665 \\
\hline Daya Hantar Listrik & 0,078 & 1,000 & & & & & & & & & 166,608 & 72,174 \\
\hline Oksigen Terlarut & $-0,541$ & $-0,650^{*}$ & 1,000 & & & & & & & & 7,765 & 0,928 \\
\hline Karbondioksida & 0,223 & $-0,267$ & 0,086 & 1,000 & & & & & & & 4,413 & 3,075 \\
\hline Ammonia & $-0,130$ & 0,165 & $-0,153$ & $0,710^{*}$ & 1,000 & & & & & & 0,210 & 0,394 \\
\hline Total Alkalinitas & 0,274 & $0.974^{*}$ & $-0,766^{*}$ & $-0,300$ & 0,068 & 1,000 & & & & & 98,567 & 8,814 \\
\hline Nitit & $-0,158$ & $-0,413$ & 0,088 & $-0,522$ & $-0,710^{*}$ & $-0,347$ & 1,000 & & & & 0,005 & 0,001 \\
\hline $\mathrm{pH}$ & $-0,799^{*}$ & 0,224 & 0,045 & $-0,633^{*}$ & $-0,12$ & 0,113 & 0,426 & 1,000 & & & 7,583 & 0,204 \\
\hline Turbiditas & 0,476 & $-0,578$ & 0,481 & 0,273 & $-0,333$ & $-0,494$ & $-0,062$ & $-0,768^{*}$ & 1,000 & & 0,402 & 0,180 \\
\hline Kelimpahan & \multirow{2}{*}{0,057} & \multirow{2}{*}{$-0.937^{*}$} & \multirow{2}{*}{$0,634^{*}$} & \multirow{2}{*}{0,048} & \multirow{2}{*}{$-0,477$} & \multirow{2}{*}{$-0,873^{*}$} & \multirow{2}{*}{0,527} & \multirow{2}{*}{$-0,268$} & \multirow{2}{*}{$0.718^{*}$} & \multirow{2}{*}{1,000} & \multirow{2}{*}{61,387} & \multirow{2}{*}{52,812} \\
\hline Larva Ikan & & & & & & & & & & & & \\
\hline
\end{tabular}




\section{Bahasan}

Identifikasi larva ikan dengan tingkat taksonomik yang lebih dalam dengan menggunakan sekuen DNA memiliki keakuratan lebih tinggi dibandingkan identifikasi secara konvensional dengan pengamatan morfologi (Azmir et al., 2017). Penelitian sekuen DNA dilakukan melalui analisis parsial mtDNA untuk membahas hubungan filogenetik antara larva ikan di danau Ranau. Hubungan genetik antara spesies larva-larva ikan ini dengan memanfaatkan fragmen sebagian dari Mitochondrial c oxidase subunit-1gene (CO1). Upaya mengevaluasi keanekaragamanhayati dengan benar adalah penting untuk memperjelas batas spesies, hubungan filogenetik, dan keterkaitan (Frankham et al., 2002). Penanda molekuler, wilayah 570 bp dari gen mapan cyctochrome c oxidase I (COI) telah berhasil ditemukan sebagai spesies spesifik, dan juga lebih bervariasi antar spesies daripada spesies (Hebert et al., 2003). Penelitian ini merupakan langkah penting untuk memahami hubungan evolusi larva-larva ikan yang hidup di Danau Ranau

Posisi organisme pada pohon filogeni umumnya didasarkan pada kesamaan genetik mereka satu sama lain. Pohon filogeni pada Gambar 3 menunjukkan hubungan evolusioner yang disimpulkan diantara beberapa spesies larva-larva ikan, genus dan famili. Organisme dari spesies yang berbeda dari genus yang sama akan berdekatan satu sama lain di pohon, pada genera yang berbeda tentunya jarak lebih jauh pada pohon filogeni, seperti pada Oreochromis mossambicus dan Gambusia affinis. Hasil analisis sekuen DNA pada 68 spesies larva ikan yang dikumpulkan dari Danau Ranau dipilih untuk dipelajari hubungan kekerabatannya. Identifikasi spesies larva-larva ikan Danau Ranau yang didapatkan berdasarkan sekuen DNA antara lain Rasbora argyrotaenia, Puntius tetrazona, Oreochromis mossambicus, Oreochromis niloticus, Dermogenys pusilla, Gambusia affinis, Poecilia reticulate, Mystacoleucus marginatus, Channa striata dan Trichopsis vittata.

Informasi mengenai hubungan evolusioner garis keturunan genetik dapat diperoleh dari sekuen DNA melalui rekonstruksi filogeni (Freeland, 2005). Pohon filogeni mencerminkan berapa banyak perubahan genetik telah terjadi dan berapa banyak waktu telah berlalu, karena garis keturunan terbelah satu sama lain, karena panjang cabang mencerminkan jarak evolusioner antara dua titik di pohon. Analisis filogenetik sangat berharga dalam biologi evolusioner, pohon sesuai untuk kelompok taksonomi pada tingkat spesies dan seterusnya, yang telah mengalami masa isolasi reproduksi cukup lama untuk memungkinkan fiksasi alel yang berbeda (Freeland, 2005). Pohon filogeni larva-larva ikan di Danau Ranau menunjukkan informasi mengenai hubungan evolusioner garis keturunan genetik hasil identifikasi sekuen DNA.
Dendogram NJ (Neighboard Joining) berdasarkan jarak genetik berpasangan menunjukkan segregasi Oreochromis mossambicus dan Oreochromis niloticusdalam satu klaster (Gambar 4). Rasbora argyrotaenia, Puntius tetrazona, Trichogaster trichopterus,Gambusia affinis, Poecilia reticulata, Mystacoleucus marginatus, Channa striata dan Trichopsis vittata pada kelompok lain dengan jarak simpul berkisar antara 0,209 menjadi 0,240 (Tabel 3). Estimasi NJ dan estimasi bootstrap dalam penelitian ini menunjukkan jarak genetik minimum $(0,255)$ antara kedua spesies ini (Trichopsis vittata dan Mystacoleucus marginatus), yang menekankan hubungan evolusioner.

Secara keseluruhan hasil penelitian yang diperoleh menjelaskan bahwa larva-larva ikan antar populasi di Danau Ranau memiliki jarak genetik yang dekat satu dengan yang lain. Kedekatan genetik antar populasi ini memberikan dugaan bahwa diantara populasi tersebut berasal dari kelompok keturanan yang sama. Genom mitokondria memiliki banyak sifat yang membuatnya berguna untuk merekonstruksi filogenetik. Fitur yang paling penting adalah warisan klonalnya. Genom mitokondria ikan adalah haploid dan nampaknya tidak rekombinasi. Oleh karena itu, evolusi dari molekul itu sesuai persis dengan model pohon evolusi bifurkasi. Mitokondria DNA berkembang lebih cepat daripada kebanyakan gen inti, memungkinkan informasi identifikasi karakter filogenetik di antara spesies dan populasi keduanya terkait erat (Kocher \& Stepien, 1997).

Oreochromis niloticus dan Oreochromis mossambicus merupakan spesies invasif yang memiliki potensi tinggi untuk dibudidayakan sebagai komoditas ikan konsumsi di Keramba Jaring Apung (KJA) milik masyarakat di Danau Ranau. Hubert et al. (2015) menyatakan bahwa spesies invasif seperti Oreochromis niloticus dan Oreochromis mossambicus, ikan gupi seperti Poecilia reticulata di Indonesia memiliki potensi tinggi untuk akuakultur dan terkadang mendominasi biomassa komunitas ikan, walaupun beberapa kandidat spesies milik genus yang sama sudah tersedia di ichthyofauna asli Indonesia.

Hasil larva ikan yang diidentifikasi dengan sekuen DNA yang dominan didapatkan selama penelitian adalah larva ikan nila Oreochromis niloticus. Proses perkembangan larva ikan telah ditentukan oleh cetak biru genetik, tapi pada waktu dan proses terjadinya dipengaruhi oleh lingkungan eksternal (faktor fisika dan kimia perairan) (Raharjo et al., 2011). Ini membuktikan bahwa ikan nila mampu tumbuh dan berkembang di perairan Danau Ranau. Ikan nila (Oreochromis niloticus) dapat tumbuh dan berkembang dengan baik disebabkan ikan tersebut memanfaatkan relung ekologi banyaknya tumbuhan air (Purnomo, 2010). 
Keberhasilan proses rekrutmen populasi ikan merupakan salah satu faktor penentu kondisi stok ikan di perairan. Hal ini sangat dipengaruhi oleh keberhasilan larva ikan untuk menjadi rekrut baru dan tumbuh (Koster \& Mollman, 2000). Salah satu cara yang paling efektif untuk memantau proses rekrutmen pada ikan adalah dengan mengkuantifikasi dan mengklasifikasikan ichthyoplankton (larva ikan). Namun, mengidentifikasi ikan dengan benar berdasarkan karakter morfologi sangat sulit, terutama pada tahap awal perkembangan (larva ikan) (Frantine-Silva et al., 2015).Diperlukan upaya perlindungan berbagai jenis larva ikan yang terancam punah dan melindungi habitat larva ikan dari degradasi kondisi perairan di Danau Ranau sehingga larva ikan dapat tumbuh dan berkembang dan diharapkan rekrutmen populasi larva ikan berhasil.

Pengelompokkan stasiun hasil PCA (principle component analysis) dijelaskan dapat dikelompokkan berdasarkan penciri habitatnya. Hasil analisa PCA dan analisis korelasi dengan uji-t pada setiap parameter menggambarkan adanya keterkaitan erat antara kelimpahan larva ikan terhadap turbiditas, total alkalinitas dan konduktivitas. Sedangkan keberadaan parameter daya hantar listrik (konduktivitas) dan total alkalinitas signifikan dan bersifat korelasi negatif terhadap kelimpahan larva ikan. Berdasarkan analisa tersebut didapatkan bahwa kelimpahan larva ikan didukung oleh kekeruhan (turbiditas), oksigen terlarut, dan $\mathrm{pH}$ yang masih dalam standar baku mutu kehidupan hewan akuatik seperti, ikan. Kelimpahan larva ikan dipengaruhi oleh $\mathrm{pH}$, konduktivitas, oksigen terlarut dan berhubungan dengan nilai antara variabel lingkungan (Gogola, 2010).

Kelimpahan larva ikan tertinggi pada stasiun Lumbok Lampung. Hal ini dikarenakan nilai oksigen terlarut dan turbiditas (kekeruhan) yang tinggi menguntungkan larva ikan yang hidup pada stasiun ini. Kekeruhan (turbiditas) berpengaruh terhadap jarak pandang organisme aquatik. Larva ikan memanfaatkan turbiditas untuk menghindar dari serangan predator. Kekeruhan yang tinggi dapat mengurangi keberhasilan predator yang memakan ikan, dan dapat menurunkan keberhasilan mencari makan dari pesaing lainnya (Richardson et al., 1995). Strategi reproduksi dapat meminimalkan pemangsaan dan memaksimalkan pemanfaatan makanan, karena memungkinkan ikan untuk mencapai tahap perkembangan lanjutan, sementara sebagian besar spesies lain bertelur (Bialetzki et al., 2002). Nilai kelimpahan larva ikan yang terendah didapatkan pada stasiun Talang Teluk dimana didapatkan nilai kekeruhan (turbiditas) yang rendah. Di perairan yang memiliki nilai alkalinitas rendah dapat menyebabkan perubahan $\mathrm{pH}$, sehingga perairan dengan alkalinitas lebih tinggi mempunyai sistem penyangga yang baik sehingga fluktuasi pH makin rendah (Effendi, 2003).

\section{KESIMPULAN}

Identifikasi spesies larva ikan di Danau Ranau dengan sekuen DNA didapatkan sepuluh jenis larva ikan yang didominasi jenis ikan nila Oreochromis niloticus. Hubungan filogeni spesies diantara takson larva-larva ikan di Danau Ranau berdekatan. Larva-larva ikan antar populasi memiliki jarak genetik yang dekat satu dengan yang lain. Kelimpahan larva ikan didukung oleh kondisi perairan. Kelimpahan larva ikan berkorelasi positif secara nyata dengan kekeruhan (turbiditas).

\section{PERSANTUNAN}

Karya Tulis Ilmiah (KTI) ini merupakan kontribusi dari kegiatan penelitian pada T. A. 2017 di Balai Riset Perikanan Perairan Umum dan Penyuluhan Perikanan, Palembang. Penulis mengucapkan terimakasih kepada Prof. Dr. Ir. Agus Djoko Utomo, M.Si., Ir.Samuel dan Ir. Siti Nurul Aida M. P. (BRPPUPP), Prof. Dr. Ir. Ngurah N. Wiadnyana, DEA, Prof. Husnah dan Dr. Eko Prianto (Puriskan) atas bimbingan dan ilmunya dalam penelitian dan tulisan ini.

\section{DAFTAR PUSTAKA}

Azmir,I. A., Esa, Y., Amin, S.M.N., Yasin, I.S. Md., \& Yusof, F.Z. (2017).Identification of larval fish in mangrove areas of Peninsular Malaysia using morphology and DNA barcoding methods.Journal of Applied Ichthyology, 33, 1-9. doi:10.1111/jai.13425.

American Public Health Association (APHA).(2005). Standard Methods for the Examination of Water and WasteWater (1193 pp). $21^{\text {th }}$ Edition. Washington D.C: Publication Office Health Association. 1193pp.

Bialetzki, A., Nakatani, K., Sanches, P. V., \& Baumgartner.(2002). Spatial and temporal distribution of larva and juveniles of Hoplias Aff.Malabaricus (Characiformes, Erythrinidae) in the Upper Parana River Floodplain, Brazil. Journal of Biology, 62, 211222.

Cole K.S. (2008). Observations on spawning behavior and periodicity in the bluegreen chromis (Pomacentridae: Chromis viridis), in Madang Lagoon, Papua New Guinea. Aqua. 4(1), 27 - 34.

Effendi, H. (2003).Telaah kualitas air. Yogyakarta: Kanisius.260 pp.

Frantine-Silva, W., Sofia, S. H., Orsi, M. L., \& Almeida, F. S. (2015).DNA barcodingof freshwater ichthyoplankton in the Neotropics as a tool for ecological monitoring.Molecular Ecology Resources, 15, 1226-1237. doi:10.1111/1755-0998.12385. 
Frankham, R., Ballou, J.D., \& Briscoe, D.A. (2002). Introduction to Conservation Genetics (p. 595). United Kingdom: Cambridge University Press.

Fuentes, M.L.E., Coto, C.F., Anorve, L.S., \& García, F.Z., (2009). Vertical distribution of zooplankton biomass and ichtyoplankton density an annual cycle on the Continental Shelf of the Southern Gulf of Mexico.Revista of Biologia Marina Oceanografia, 44(2), 477-488.

Gogola, T.M., Daga, V.S., da Silva, P.R.L., Paulo V. Sanches, P.V., Gubiani, E.A., Baumgartner, G., \& Delariva, R.L. (2010). Spatial and temporal distribution patterns of ichthyoplankton in a region affected by water regulation by dams. Neotropical Ichthyology, 8(2), 341349.doi:10.1590/s1679-62252010000200013.

Hall, T.A. (1999). BioEdit: a user-friendly biological sequence alignment editor and analysis program for Windows 95/98/NT. Nucleic Acids SympSer, 4, 95-98.

Hebert, P.D.N., Sujeevan R, Jeremy R. (2003). Barcoding animal life: cytochrome c oxidase subunit 1 divergences among closely related species. Proceeding Biology Science, 270, S96S99.doi:10.1098/rsbl.2003.0025.

Hubert, N., Kadarusman., Wibowo, A., Busson, F., Caruso, D., Sulandari, S., Nafiqoh, N., Pouyaud, L., Ruber, L., Avarre, J.C., Herder, F., Hanner, R., Keith, P., \& Hadiaty, R.K. (2015). Review: DNA Barcoding Indonesian freshwater fishes: challenges and prospects. DNA Barcodes, 3, 144 -169.doi:10.1515/dna-2015-0018.

Husnah, Eko,P., \& Aida, S.N. (2007). Kualitas perairan Sungai Musi bagian hilir ditinjau dari karakteristik fisika kimia dan struktur komunitas makrozoobenthos. J.Lit.Perikan.Ind, 13(3), 167-177. DOI: http:// dx.doi.org/10.15578/jppi.13.3.2007.167-177

Ivanova, N.V., Zemlak, T.S., Hanner, R.H., and Hebert, P.D.N. (2007).Universal.Primer cocktails for fish DNA barcoding. Molecular Ecology Notes, 7, 544548.doi:10.1111/j.1471-8286.2007.01748.x.

Kocher, T.D., \& Stepien, C.A. (1997). Molecular systematics fishes (p. 314). United States of America: Academic Press.

Koster, F.W., \& Mollmann, C. (2000).Trophodynamic control by clupeid predators on recruitment success in Baltic cod.ICES Journal of MarineScience, 57, 310 323.doi:10.1006/jmsc.1999.0528.
Marc, K., Robert, B.B., \& Brian, R. (ed.). (2009). Trends in fishery genetics.In: The future of fisheries science in North America. Berlin: Springer Science.

Meffe, G.K. \& Vrijenhoek, R.C. (1988). Conservation genetics in the management of desert fishes. Conservation Biology, 2, 157169.doi:10.1111/j.1523-1739.1988.tb00167.x.

Nei, M. (1972).Genetic distance between populations.American Naturalist. 106, 283292.doi:10.1086/282771.

Nugroho, Estu., Hadie, W., \& Sudarto. (2003). Variasi genetik ikan baung (Mystus nemurus) dari beberapa Waduk di Jawa yang dianalisis dengan marker mitokondria D-Loop.Jurnal Penelitian Perikanan Indonesia, 9(1), 1-5.DOI: http://dx.doi.org/10.15578/ jppi.9.1.2003.1-5.

Purnomo, K. (2000). Kompetisi dan Pembagian Sumberdaya Pakan Komunitas Ikan di Waduk Wonogiri.Jurnal Penelitian Perikanan Indonesia. 6(3): 16-23.

Raharjo, M.F., Syafei, D.S., Affandi, R.A., Sulistiono.,\& Hutabarat, J. (2011). Iktiology. Bandung: Lubuk Agung. 396pp.

Richardson, M.J., Whoriskey, F.G., \& Roy, L.H. (1996).Turbidity generation and biological of an exotic fish Carassius auratus, Introduced into shallow seasonally anoxic ponds.Journal of Fish Biotogy, 47, 576-588.doi:10.1111/j.1095-8649.1995.tb01924.x.

Samuel.,\& Subagja. (2011). Karakteristik habitat dan biologi ikan mujaer (Oreochromis mossambicus) di Danau Ranau, Sumatera Selatan.BAWAL. 3(5): 287297.DOI: http://dx.doi.org/10.15578/ bawal.3.5.2011.287-297

Sanger F, Nicklen S., \& Coulson AR. (1977).DNA sequencing with chain-terminating inhibitors.National Academical Science, 74 (12), 5463-5467.doi:10.1073/ pnas.74.12.5463.

Setijanto, Chaeri,A., \& Nursid, M. (2003).Kelimpahan Larva Ikan Engraulidae dan Hubungannya dengan Parameter Lingkungan di Estuaria SegaraAnakan Cilacap, Jawa Tengah, Indonesia.Jurnal Penelitian Perikanan Indonesia, 9(7), 59 - 66.DOI: http://dx.doi.org/ 10.15578/jppi.9.7.2003.59-66.

Stouthamer, C. E., \& Bain, M. B. (2012).Quantifying Larval Fish Habitat in Shoreline and Shallow Waters of the Tidal Hudson River. Section VII: 1-25 pp. In S.H. 
Fernald, D.J. Yozzo and H. Andreyko (Eds.).Final Reports of the Tibor T. Polgar Fellowship Program in 2010.Hudson River Foundation. Section VI: 1-25 pp

Sulastri, Badjoeri, M.., Sudarso, Y.,\& Syawal, M.S. (1999). Kondisi Fisika Kimia dan Biologi Perairan Danau Ranau Sumatera Selatan.. Limnotek. 6(1): 25-38.

Thompson, J.D., Gibson, T.J., Plewniak, F., Jeanmougin, F., \& Higgins, D.J. (1997). The clustal X windows interface: Flexible strategies for multiple sequences alignment aided by quality analysis tool. Nucleic Acid Res, 25(24), 4876-4882. doi:10.1093/nar/25.24.4876.

Tamura, K., Dudley, J., Nei, M., \& Kumar, S. (2007). MEGA4: Molecular Evolutionary Genetics Analysis (MEGA) software version 4.0. Molecular Biology and Evolution, 24, 1596-1599.doi:10.1093/molbev/msm092.

Uriarte, I., \& Fernando, V. (2005). Difference in theabundance and distribution of copepods in Two Estuaries of Bascque Coast (Bay of Biscay) in relation to pollution. Journal of Plankton Reasearch. 27(9): 863 -874. DOI: https://doi.org/10.1093/plankt/fbi059

Wulandari, T.N.M., Herlan.,\& Wibowo, A. (2018). Identifikasi Beberapa Spesies Ikan Dengan Sekuens DNA di Danau Cala, Sumatera Selatan. Dalam Prosiding Pertemuan Ilmiah Masyarakat Limnologi Indonesia Tahun 2017 (pp. 192-197). Bogor, Indonesia: Kongres dan Pertemuan Ilmiah Tahunan III MLI. 